\title{
LíDIA BALOGH*
}

\section{Racist and Related Hate Crimes in Hungary - Recent Empirical Findings}

\section{An overview of the situation concerning hate crimes in Hungary}

\section{Affected communities}

In Hungary the Roma constitute the largest minority (the estimated number of the Roma population is $700000,{ }^{1}$ which is approximately $7 \%$ of Hungary's total population), and practically the Roma are the only "visible" minority (given the small proportion of migrants in the population). ${ }^{2}$ Given that the Roma are often used as scapegoats for social and economic problems, and prejudices and negative attitudes against Roma are pervasive in the mainstream Hungarian society, hate crimes or hate speech as an issue might come up first of all in the context of anti-Roma tensions in Hungary.

Anti-Semitism is to be considered as a prevalent phenomenon in Hungary (including the political discourse), and there are numerous cases of attacks against the members of the Jewish community, which is estimated to be between 80000 and $100000,{ }^{3}$ or vandalism against Jewish property.

Other racist manifestations are not significant. The only known Islamophobic incident in 2009, when civil protesters, supported by local politicians, opposed the opening of a Muslim cultural centre in Budapest, might not be considered as an example for hate crime.

Manifestations of hate crimes are reported against LGBT people in Hungary. Allegedly, a large proportion of homophobic hate crimes (including violent attack against persons and verbal abuses) is committed around the time of the annual Gay Pride March in Budapest. This trend started in 2007, and there was an enormous amount of violent attacks against the Pride March in 2008.

* Ph.D. candidate, Eötvös Loránd University, Budapest.

E-mail: lidia.balogh@gmail.com

1 Council of Europe's data: http://www.coe.int/t/dg3/romatravellers/default_en.asp

2 According to the the Central Statistical Office, the proportion of foreigners is $1.7 \%$ in the whole population living in Hungary, among them a large proportion is of ethnic Hungarians, coming from the neighbouring countries. See details on the methods of measuring migrant population in Hungary: Hárs, Á.: A harmadik országokból Magyarországon tartózkodó külföldi állampolgárok a statisztikai adatok tükrében (The statistics of third-country nationals residing in Hungary). In: Bevándorlók Magyarországon. Az MTA Etnikai-nemzeti Kisebbségkutató Intézet ICCR Budapest Alapítvány által végzett kutatás zárótanulmányai (Immigrants in Hungary. Final report of the research implemented by the Institute for Ethnic and National Minority Studies of the Hungarian Academy of Sciences and the ICCR Budapest Foundation). Budapest, 2009, 28.

3 U.S. Bureau of Democracy, Human Rights, and Labor: 2009 Human Rights Report: Hungary, 2010, available at http://www.state.gov/g/drl/rls/hrrpt/2009/eur/136035.htm 


\section{Notable contexts of racist manifestations}

In 2009, during the EP election campaign, the National Election Commission held that the extreme-rightist Jobbik party's slogan "Hungary belongs to Hungarians" is unconstitutional. ${ }^{4}$ However, no further sanctions were issued, and the slogan was continued to be used. Homophobic statements were also recurring themes in Jobbik rallies during the 2009 EP-elections campaign. A week after the MEP elections Jobbik announced at a press conference that they would work in close cooperation with other right-wing extremist political groups to stop the Gay Pride March by all means necessary.

Also 2009, the Ethics Committee of the Association of Hungarian Journalists condemned a rightist weekly Magyar Fórum ${ }^{5}$ for portraying a prime minister candidate on its cover framed in a Star of David saying "Jewish Prime minister". The Association held that the cover violates the constitution and human dignity and asked the Parliamentary Commissioner of Civil and Political Rights to investigate the case.

Extremist news media releases ${ }^{6}$ often refer to crimes involving alleged Roma perpetrators, as "a crime of the Gypsies", and the term is used even for cases when there is a lonely perpetrator, or when the ethnicity of the perpetrator(s) is unknown. ${ }^{7}$

Despite some governmental efforts aimed at combating racist incitement on the internet, extremist websites (in Hungarian language) are still operating. In June 2009, human rights NGOs filed a report, with the National Police and the Capital Prosecutor's Office, claiming investigation and indictment for inciting ethnic hatred, against a notorious and widely known right-wing extremist blogger (who posted to his blog that Roma people should be "subjugated, expelled from public and cultural life and any utterance of ethnic nature has to be eliminated without mercy. Their spines have to be broken"). ${ }^{8}$

Racist/intolerant manifestation in sports-first of all verbal abuse, and banners displaying hate speech or holocaust denial on the grandstands-appears practically only in the context of football in Hungary. The Hungarian Football Federation" regularly fines the violators of the regulations regarding "acceptable behaviour".

4 OVB: Az országos választási bizottság 2009. június 3-án megtartott ülésének jegyzőkönyve. Budapest, 2009 (Record on the meeting of the National Election Commission held on 3rd of June, 2009), available at http://www.valasztas.hu/hu/ep2009/content/of/20090603.pdf

5 MÚOSZ: Etikai Bizottság: törvénysértő a Magyar Fórum címlapja. 2009 (Ethics Committee: The front page of Magyar Fórum violatest the law) (27.03.2009) available at http://muosz.hu/cikk.php?page=bizottsagok\&id=1908\&fo=8\&iid $=5$

${ }^{6}$ For example the extreme rightist web page www.kuruc.info is operated from various international servers; it has been banned several times due to complaints, but is restarted again and again from a different server.

7 Balogh, L.: Etnikai adatok kezelése a magyarországi sajtóban (Ethnic data handling in the Hungarian media). In: Föld-rész, 2, (2009) 3-4, 89-90.

8 Jogi Fórum/Magyar Helsinki Bizottság: Jogvédő szervezetek feljelentést tettek a BRFK-n és a Fővárosi Föügyészségen közösség elleni izgatás miatt (Human rights NGO filed a complaint at the Budapest Police Headquarter and at the Budapest Chief Prosecutor's Office on incitement against community). Jogi Fórum (26.06.2009) available at: http://www.jogiforum.hu/hirek/21009

9 Magyar Labdarúgó Szövetség: www.mlsz.hu 
Attention received by racist crime and other forms of hate crime

In the last two years, apparently hate crimes against the Roma attracted the most significant media attention, compared to other forms of hate crimes. However, as a recent study shows, ${ }^{10}$ the media attention was significantly higher regarding those cases where allegedly Roma perpetrator committed violent crimes against non-Roma victims, compared to the attention regarding hate crimes against Roma victims. As for anti-Semitic and homophobic hate crimes, there are occasional reporting of such incidents in the media, however, according to NGO sources, a large proportion of hate crimes do not receive any media attention, because these incidents tend to remain unreported.

Besides awareness raising activities and demonstrations organised by civil society actors responding to hate crimes affecting members of the Roma or Jewish communities, ${ }^{11}$ notable NGO actions, reacting to inappropriate police responses to hate crimes, took place. In 2009, three NGOs (European Roma Rights Centre, Legal Defence Bureau for National and Ethnic Minorities the Hungarian Civil Liberties Union) released a joint report ${ }^{12}$ about the misconducts of the relevant authorities regarding the investigation of the fatal attack against a Roma family in Tatárszentgyörgy. In 2010, the Hungarian Civil Liberties Union submitted a petition to the Head of the National Police and the Head of the Budapest Police Headquarters regarding an attack against the home of a Jewish family on Seder evening, which was considered and investigated by the police as "vandalism", instead of "violence against members of a community". ${ }^{13}$ Also in 2010, an open letter was sent to the Head of the Budapest Police Headquarters by the Hungarian Civil Liberties Union, ${ }^{14}$ regarding the attacks against the participants 2010 Gay Pride March in Budapest, which were considered and investigated by the police as "disorderly conducts" or "minor bodily injuries" instead of "violence against members of a community".

10 Karácsony, G.-Róna, D.: A Jobbik titka. A szélsőjobb magyarországi megerősödésének lehetséges okairól (The secret of Jobbik Party: on the possible causes of the sweep of Right Wing on Hungary). Politikatudományi Szemle, 19 (2010) 1, 31-66.

${ }^{11}$ For example on 23 February 2010, the Méltóságot Mindenkinek Mozgalom (Dignity for All Movement) organised a Remembrance Day on the anniversary of the double murder in Tatárszentgyörgy, where a 27-year-old Roma man and his five-year-old son were shot and killed; in April 2010, the Szabad Emberek Magyarországért (Free Persons for Hungary) organised a peaceful "walk in kipa or headscarf", aimed at protesting against the inappropriate police response and showing solidarity towards religious Jews living in Hungary.

12 European Roma Rights Centre, Legal Defence Bureau for National and Ethnic Minorities and Hungarian Civil Liberties Union: Report on the circumstances of the double murder committed at Tatárszentgyörgy on 23 February 2009 and the conduct of the acting authorities (the police, ambulance and fire services), 2009, available at http://www.errc.org/cms/upload/media/03/DA/ m000003DA.pdf

13 TASZ: Nem rongálás, közösség tagja elleni erőszak-rendörséghez fordul a TASZ a Széder estet ünneplök megtámadása ügyében (Not vandalism, but violence against members of a communityHungarian Civil Liberties Union turns to the police regarding the attack against participants of a Seder Eve celebration). (01.04.2010), available at http:/tasz.hu/szolasszabadsag/nem-rongalas-kozossegtagja-elleni-eroszak-rendorseghez-fordul-tasz-szeder-estet-unn

14 TASZ: A melegeket ért támadások miatt a BRFK-hoz fordultunk (We turned to the Budapest Police Headquarter because of the attack against gays). (06.07.2010), available at http://tasz.hu/hirek/ tasz-level-budapest-rendorfokapitanyanak 
As for the attention of international organisations, apparently the issue of anti-Roma hate crimes (committed in 2008-2009) received the most of attention.

In June and July 2009, Andrzej Mirga, the Senior Advisor on Roma and Sinti Issues, Office for Democratic Institutions and Human Rights of the Organisation for Security and Co-operation in Europe, led a nine-day field assessment visit to Hungary to explore possible factors leading or contributing to the attacks on and killings of Roma and the responses of the authorities to these incidents. The delegation visited 12 localities in Hungary, and met with representatives of the central, regional and local government, of the police and of the civil society. ${ }^{15}$

The Council of Europe Commissioner for Human Rights visited Hungary in October 2009 to discuss issues related to fight against intolerance affecting members of minority groups. ${ }^{16}$ Regarding the Hungarian situation, the Commissioner "stressed the need to increase public awareness on the situation of minorities which suffer from systematic discrimination or intolerance, such as the Roma, the Jewish community and LGBT (lesbian, gay, bisexual, transgender) people". ${ }^{17}$

\section{The legal context regarding hate crimes in Hungary}

\section{Current legal framework on and recent developments}

Regarding the relevant time period (2005-2010), the Hungarian Criminal Code ${ }^{18}$ criminalised six types of behaviour that may fall under the racially/hate motivated category. These are: genocide $;{ }^{19}$ apartheid $;{ }^{20}$ violence against member(s) of a community; ${ }^{21}$ incitement against community; ${ }^{22}$ ban of using totalitarian symbols, ${ }^{23}$ ban of denying, doubting, or trivialising genocide or crimes against humanity committed by totalitarian regimes. ${ }^{24}$

The article of the Criminal Code on violence against member(s) of a community ${ }^{25}$ was amended in 2008. ${ }^{26}$ As a result, this article of the Criminal Code, governing previously "violence against a member of a national, ethnic, racial or religious group", was extended to cover any group of the population. The name of the offence was also modified to "violence against member(s) of a community". As a result of the amendment, individuals engaged in the preparation of violence against a member of a community shall also be held criminally

15 See ODIHR: E-newsletter. July-August 2009, available at http://archive.constantcontact.com/ fs026/1101200403519/archive/1102659952399.html

16 The focus of the discussions was on anti-Roma hate-crimes in Hungary.

17 Office of the Commissioner for Human Rights Communication Unit: Hungary: Commissioner Hammarberg recommends further action to eradicate intolerance and discrimination, 2009. (Press Release-762(2009), available at: https://wcd.coe.int/ViewDoc.jsp?id=1520817\&Site=DC

18 Act No. IV of 1978.

19 Ibid. Art. 155.

20 Ibid. Art. 157.

21 Ibid. Art. 174/B.

22 Ibid. Art. 269.

23 Ibid. Art. 269/B (since the amendment of the Criminal Code in 1993).

24 Ibid. Art. 269/C.

25 Ibid. Art. 174/B.

26 On 10 November 2008, the Hungarian National Assembly adopted Act No. LXXIX of 2008, on Certain Amendments Necessary to Protect Public Order and the Operation of the Judiciary, which modified Article 174/B of the Criminal Code, effective from 1 February 2009. 
liable. ${ }^{27}$ Based on the amendments, the new provision is the following: (1) Any person who assaults another person for being part, whether in fact or under presumption, of a national, ethnic, racial, or religious group, or certain groups of the population, or compels her/him by applying coercion or duress to do, not to do, or to endure something, is guilty of a felony punishable by imprisonment for up to five years. (2) The punishment shall be imprisonment between two to eight years if the act or crime is committed: a) by force of arms; b) with a deadly weapon; c) causing a considerable injury of interest; d) with the torment of the injured party; e) as part of a group; or, f) as part of a criminal conspiracy. (3) Any person who engages in preparing violence against a member of a community is guilty of a misdemeanour punishable by imprisonment for up to two years.

The article of the Criminal Code on incitement against community ${ }^{28}$ provides with protection against non-violent conduct motivated by racism, xenophobia or other bias motive (e.g. homophobia ${ }^{29}$ ), according to which anyone publicly inciting hatred against the Hungarian nation or any national, ethnic, racial or other groups of the population shall face punishment for a felony offence with imprisonment for up to three years.

The article of the Criminal Code on ban of denying, doubting, or trivialising genocide or crimes against humanity committed by totalitarian regimes ${ }^{30}$ originally dealt only with holocaust denial or trivialising (it came into force in February 2010). A few months later, as a result of legislative initiatives of the newly elected Hungarian government, this subparagraph was amended (entered into force in July 2010). The new version of this paragraph is extended to the crimes of both "national socialist" and "communist regimes", and the term "holocaust" is no longer there in the text.

Other relevant development is the amendment to Criminal Code in February 2010, which punishes participating in the leadership or in some cases the mere activities of banned associations (e.g. in extremist associations: consider the amendment of the Act on Petty Offences) with up to three years of imprisonment. ${ }^{31}$

Certain articles of the Criminal Code, such as those covering murder (homicide) ${ }^{32}$ or the causing of grievous bodily harm (battery) ${ }^{33}$ expressly grant judges the discretion to take into account "base motivations" when sentencing offenders, therefore judges in such cases may thus take racist or other bias motivation into account as an aggravating circumstance.

\section{Concerns and debates regarding legislation in the field of racist and other hate crimes}

While judges may take racist or other bias motivation into account as a "base motivation", however, racist or other bias motivation is not expressly listed in the relevant provisions of the Criminal Code. No general provision exists in Hungarian law under which racist or

27 Act No. LXXIX of 2008, Art. 2.

28 Act No. IV of 1978, Art. 269.

29 See the interpretation of the law regarding homophobic hate crimes on the website of the (former) Ministry of Social Affairs and Labour: Jogi hátter-Magyar jogszabályok (Legal background - Hungarian laws). available at http://szmm.gov.hu/main.php?folderID=21369\&articleID=42416\&cta $\mathrm{g}=$ articlelist\&iid $=1$

30 Act No. IV of 1978, Art. 269/C.

31 Act No. XXXV of 2010 on the Amendment of the Criminal Code (Act No. IV. of 1978), amending Art. 212/A of the Criminal Code.

32 Act No. IV of 1978, Art. 166.

33 Ibid. Art. 170. 
other bias motivation constitutes an express aggravating circumstance in ordinary criminal offences. Concerning this situation, the ECRI recommends ${ }^{34}$ that the Hungarian authorities draft a "specific provision that would make racist motivations aggravating circumstances for ordinary offences", "as without such a systematic approach, the racial motivations of offenders are not assessed on a consistent basis".

As for the new provisions of the Criminal Code on the ban of denying, doubting, or trivialising genocide or crimes against humanity committed by totalitarian regimes, ${ }^{35}$ the Hungarian Civil Liberties Union expressed concerns in May 2010, stating that the (by that time, planned) measure curtails the rights to freedom of opinion and freedom of expression, and violates the principle of academic freedom as well. ${ }^{36}$

Although the Act on Assembly prohibits demonstrations that would violate criminal provisions, ${ }^{37}$ the same act only allows for the police to prohibit demonstrations if it would obstruct the functioning of crucial state institutions or would practically impede traffic. ${ }^{38}$ Thus, demonstrations obviously carrying the risk of foreseeable violence and the intimidation of a great number of people cannot be banned, only disbanded. (Consider the example of August 2009, when international neo-Nazi organisations were planning a demonstration in Budapest to commemorate the death of Hitler's deputy, Rudolf Hess.) $)^{39}$

After the Gay Pride March in July 2008, former interpretation of relevant law, according to which throwing eggs at people appearing at public events was considered to be within the boundaries of the freedom of expression ${ }^{40}$ was changed, and throwing objects at participants at public events was considered as "infamation" by the Chief Prosecutor of Budapest, and later by the Supreme Prosecutor as well. ${ }^{41}$ Previously, the Pest Central District Court ruled that throwing eggs is protected by the right to freedom of expression. The judgement, was criticised by several human rights NGOs, along with a number of politicians and prominent members of the judiciary, concerned dozens of rightist protesters who threw eggs, bottles and rocks at the gay pride marchers and the police. ${ }^{42}$

34 ECRI: Report on Hungary, fourth monitoring cycle. 2009, (adopted on 20 June 2008, published on 24 February 2009), 14, available at http://www.coe.int/t/dghl/monitoring/ecri/countryby-country/hungary/HUN-CbC-IV-2009-003-ENG.pdf

35 Act No. IV of 1978, Art. 269/C.

36 TASZ: A Társaság a Szabadságjogokért jogvédő szervezet véleménye A büntetö törvénykönyv módositására vonatkozó T/25. számú törvényjavaslatról (The opinion of the Hungarian Civil Liberties Union on the proposal no. T/25. on the amandement of the Penal Code). 2010, available at http://tasz. $\mathrm{hu} /$ files/tasz/imce/tasz_nemzetiszocialista_kommunista_bunok_btk2010.pdf

37 Act No. III of 1989, Art. 2.

38 Act No. III of 1989.

39 Pap, A. L.: Dogmatism, hypocrisy and the inadequacy of legal and social responses combating hate crimes and extremism-the CEE experience. Proceedings of the Conference: "Extremism and the Roma and Sinti in Europe: Challenges, Risks and Responses". OSCE-ODIHR University College London, London, 10-11 Sept. 2009. (forthcoming).

40 See Resolution No. B.4488/2007/2-I, of the Prosecutor of the V. and XIII. district of Budapest.

${ }^{41}$ MTV-információ: Becsületsértő a tojásdobálás-ügyészi válasz a liberális politikusoknak (Throwing eggs constitutes defamation-the Prosecutor's answer to liberal politicians). Jogi Fórum, 2008. available at http://www.jogiforum.hu/hirek/18311

42 TASZ: Reakció a PKKB tegnapi itéletére (Reaction to the decision of the Pest County Central Court from yesterday). 2008, available at http://tasz.hu/gyulekezesi-jog/reakcio-pkkb-tegnapiiteletere 


\section{Data and information on racist and related hate crimes}

\section{Assessment of available data and information regarding hate crimes}

Data on racist violence is limited as the police, prosecutors and courts do not usually recognise racial motivation. It is close to impossible to draw valid conclusions regarding the extent, trends and forms of racist violence and crime on the basis of official criminal justice data and information, due to the small number of cases that are actually recorded. This should by no means imply that racial crimes and violence are non-existent in Hungary. In Hungary no specific legally binding instructions exist for the determination of racially motivated criminal activity. Another debate concerns the legal status of perceived ethnicity; however, some argue that collection and handling of data relating to one's perceived ethnic origin is not explicitly prohibited by the law. ${ }^{43}$

It has to be mentioned that there are no monitoring system specialised for racist incidents in Hungary, although there are mechanisms aimed at monitoring the phenomena and racism and the situation of ethnic/national minorities, functioning in different international organisations' frameworks (i.e. UN, CoE).

Allegedly, a large proportion of anti-Rom and anti-Semitic incidents (e.g. verbal abuses, harassment) remain unreported to the police. Similarly, according to unofficial NGO-sources, majority of homophobic hate crimes remains invisible and perpetrators remain unpunished, because the victims often do not report the crime to the police due to fear of public exposure of their sexual orientation and of potential further discrimination, or in several cases the police refused to start an investigation or stopped the investigation for the lack of finding perpetrators. Initiatives aimed to establish an LGBT police organisation (which would not only empower the affected police officers themselves, but allegedly improve the situation of the victims of homophobic hate crimes as well) has not been successful so far in Hungary.

While there is no data or information on hate crimes against migrants or refugees, it should be noted that interviewees of a study about the social situation of third-country nationals living in Hungary opted not to answer the question about personal experiences about racist attacks or abuses. ${ }^{44}$

\section{Categories of incidents and crimes}

Due to the already reported data collection restrictions, it is not possible to obtain official numbers beyond the statistics of the six listed types of criminal offences (genocide; apartheid; violence against a member of a community, incitement against community; using totalitarian symbols, denying, doubting, or trivialising genocide or crimes against humanity committed by totalitarian regimes) that might contain a racial or other bias element. For example, instances of aggravated bodily harm or ill-treatment in official proceeding may

43 The Hungarian Data Protection Law (Act No. LXIII of 1992) differentiates the concept of 'sensitive data' within the category of personal data. Sensitive data, among others data on race or membership in an ethnic community, constitute a type of personal data referring to an essential trait and thus a vulnerable part of the subject's personal identity (Art. 2, Clause 2).

${ }^{44}$ Bognár, K.: Kapcsolatok és erőforrások, bevándorlók és befogadók (Relations, resources, immigrants and receivers). In: Bevándorlók Magyarországon. Az MTA Etnikai-nemzeti Kisebbségkutató Intézet ICCR Budapest Alapitvány által végzett kutatás zárótanulmányai. (Immigrants in Hungary. Final report of a research implemented by the Institute for Ethnic and National Minority Studies of the Hungarian Academy of Sciences and the ICCR Budapest Foundation). Budapest, 2009, 147. 
have racial or other bias motivations, but in the absence of relevant statistics on the aggrieved party, the patterns of racist or other bias motivations are impossible to trace. ${ }^{45}$

As for violent crimes against the person, out of the six offences, "violence against members of communities" may be drawn under this term. As it was mentioned above, potential racial or other bias motivations of other offences involving violence against the person (e.g. different degrees of bodily harm, homicide, etc.) are not recorded.

In the Hungarian Criminal Cod, there is no offence separately sanctioning violence against property motivated by racism or other bias motivation. Therefore, no official statistics are available. In individual cases (e.g. vandalism in Jewish cemeteries) the judge may in theory assess potential bias motivations as an aggravating circumstance, as a form of "base motivation", but such considerations will not appear in the court statistics, so without targeted research focusing on individual court cases no data can be provided in this respect.

Concerning verbal threats and abusive behaviour, out of the six offences listed, "incitement against community" may be drawn under this term. (The term of "harassment", 46 which typically covers verbal manifestations, is used in the context of the law on equal opportunities.)

Victim and offender characteristics: Data on the demographic features of the victims and offenders is scarce, and due to the mainstream interpretation of data protection rules, never contain any reference to ethnicity/race. Out of the six relevant offences, only "violence against members of communities" might have actual victims, however, the authorities do not collect data even on the citizenship of the victims of these offences. No data is gathered either on which community is concerned by specific instances of "incitement against community".

\section{Cases recorded by the police}

The source of the statistical data on cases registered by the police is the Unified Investigation and Prosecution Statistical Database. ${ }^{47}$ Data about cases is recorded in the system of Unified Investigation and Prosecution Statistical Database once the case is "finished" from the aspects of investigation or prosecution: till the rejection of a report or till a charge is filed, respectively.

The database refers to the relevant laws, therefore the data is presented here by the categories of offences, as defined by the Criminal Code. As mentioned above, the official data does not include a breakdown on the communities concerned, therefore no information is available on the actual proportion of anti-Semitic, Islamophobic or other hate motivated crimes among the cases.

According to the available data, in 2008 and 2009 no cases were recorded regarding "apartheid", or "denying, doubting, or trivialising genocide or crimes against humanity

45 The latest ODIHR report on hate crimes indicates as well, referring to the information provided by Hungarian authorities, that the data is not classified according to the types of crimes. See OSCE-ODIHR (2009) Hate crimes in the OSCE region-incidents and responses. Annual Report for 2008, 77, available at http://www.osce.org/odihr/item_11_41314.html

46 Act No. CXXV of 2003, Art. 10(1).

47 Egységes Nyomozóhatósági és Ügyészségi Bünügyi Statisztika (ENYÜBS). 
committed by totalitarian regimes". ${ }^{48}$ Concerning "genocide", the two cases reported by the public in 2009 were rejected ${ }^{49}$ by the police.

With respect to "violence against a member of an ethnic etc. group", one out of 13 complaints was rejected in 2008, and two of 23 cases in 2009. The investigation resulted in the establishment of a petty offence in one case in 2009. Concerning "incitement against community": 12 of the 24 cases were rejected by the police in 2008; and 24 out of 48 was rejected in 2009. The investigation resulted in the establishment of a petty offence in 2 cases, both in 2009. Regarding "use of totalitarian symbols", only eight complaints were rejected out of 255 in 2008, and 5 out of 104 in 2009. As a result of the investigation, a petty offence was established in 3 cases (all in 2009).

\section{Cases recorded by the prosecution service}

The source of the statistical data on cases recorded by the prosecution service is also the Unified Investigation and Prosecution Statistical Database.

According to the available data, in 2008 and 2009, no cases were recorded regarding "genocide"," apartheid", or "denying, doubting, or trivialising genocide or crimes against humanity committed by totalitarian regimes". 50

With respect to "violence against a member of an ethnic etc. group", eight cases in 2008 and seven cases in 2009 were filed with the prosecution service, out of which resulted in order for trial only in one case, in 2009. Concerning "incitement against community", 1-1 cases were filed in 2008 and 2009 (both resulted in indictments). Regarding "use of totalitarian symbols", 156 charges were filed in 2008, and 25 in 2009, out of which resulted in order for trial in 106 cases in 2008 and in only one case in 2009.

\section{Cases recorded by courts}

The source of the statistical data on cases recorded by courts is the Collection of Court Decisions ${ }^{51}$ which refers to the relevant legislation. ${ }^{52}$ This database contains data and the text of anonymised ${ }^{53}$ court decisions that are to be made public according to the Act on the Freedom of Information. ${ }^{54}$

According to the accessible information in the database, between 2008 and 2010, no decision in the database refers to the Criminal Code concerning "genocide", "apartheid",

48 The relevant article of the Criminal Code first came into force in February 2010 and then the amended version came into force in July 2010.

49 According to the Hungarian Criminal Procedure Code (Act No. XIX of 1998) on the Criminal Procedure Code, the police may reject a report if the reported behaviour is not a criminal offence or the suspicion of a criminal offence is absent (Art. 174).

50 The relevant article of the Criminal Code first came into force in February 2010, and then the amended version came into force in July 2010.

51 The Collection of Court Decisions is available online at: http://www.birosag.hu/engine. aspx?page $=$ anonim

52 The database is searchable by the referred articles of acts, or by the texts of the decisions.

53 The names of the parties are deleted.

${ }^{54}$ Act No. XC of 2005 on the Freedom of Information, Sec. 4 on the Collection of Court Decisions. 
"incitement against community" or "denying, doubting, or trivialising genocide or crimes against humanity committed by totalitarian regimes". 55

Concerning the illegal "use of totalitarian symbols", altogether six decisions in the database referred to the relevant part of the Criminal Code (2008: four decisions, one-one decisions in 2009 and 2010). ${ }^{56}$ Decisions show altogether nine defendants, out of which five were not found guilty. In 2008, two perpetrators were sentenced to probation, and one perpetrator was reprehended ${ }^{57}$ by the court. In 2010 one perpetrator was reprehended by the court.cConcerning "violence against a member of an ethnic etc. group", the database shows one-one cases in 2008 and 2009 (involving possible bias motivation against Roma victims, which was eventually not established by the court).

\section{Comments on developments by official sources with respect to hate crime in Hungary}

The reports and other documents issued by the Parliamentary Commissioner for the Rights of Ethnic and National Minorities provide with comments on trends and developments of racist hate crimes.

The 2005 report $^{58}$ of the Commissioner does not contain a special section on hate speech or hate crimes, and there is only one reference, mentioning that several complaints were filed by parents of Roma origin about alleged physical abuse of pupils by teachers, motivated by anti-Roma hate. The report about $2006^{59}$ contains some articles about the role of the media in stirring ethnic hatred, ${ }^{60}$ emphasizing that the responsibility of journalists is even larger "especially in such times burdened with tension". ${ }^{61}$ A hate speech case is also mentioned: the Parliamentary Commissioner ex officio reported a webpage with content (e.g. lyrics) explicitly inciting violence against the Roma. ${ }^{62}$

55 The relevant article of the Criminal Code first came into force in February 2010 and then the amended version came into force in July 2010.

${ }^{56}$ Actually, according to the available texts of the decisions regarding the illegal use of totalitarian symbols, all of these cases in the concerned period, 2008-2010, involved communist symbols (five-pointed red stars, etc.), therefore these cases would not qualify for genuine racist/bias motivated hate crimes.

57 "Reprehension" might be considered as the most moderate disciplinary measure, aimed at expressing disapproval of the issuing authority.

58 Parliamentary Commissioner for National and Ethnic Minority Rights of Hungary: A nemzeti és etnikai kisebbségi jogok országgyülési biztosának beszámolója a 2005-es évröl (Report of the Parliamentary Commissioner for National and Ethnic Minority Rights on the year 2005). Budapest, 2006, available at http://www.kisebbsegiombudsman.hu/word/04-29-2008_10_43_30/besz_2005.html

59 Parliamentary Commissioner for National and Ethnic Minority Rights of Hungary: Beszámoló a nemzeti és etnikai kisebbségi jogok országgyülési biztosának tevékenységéröl a 2006-es évben (Report on the activity of the Parliamentary Commissioner for National and Ethnic Minority Rights in 2006). Budapest, 2007 available at http://www.kisebbsegiombudsman.hu/data/files/145405078.pdf

60 Ibid. 63.

${ }^{61} \mathrm{Ibid}$. 68. 2006 was the year when demonstrations broke out after leaking of an audio recording with a speech of the then prime minister Ferenc Gyurcsány held before a closed-door meeting of the Socialist Party, stating the party had lied to the public regarding the country's economic status to win the 2006 Parliamentary elections and criticised the Socialist Party's governing. The demonstrations involved occasional violent actions, as well as extreme rightist and anti-Semitic voices.

62 Ibid. 69. 
The report on 2007 presents developments regarding the sweep of the extreme rightist Jobbik Magyarországért Mozgalom (For a Better Hungary Movement) ${ }^{63}$ party, and its political rhetoric which associates Roma ethnicity with inherent criminality, by using the term "Gypsy criminality". The report includes a chapter on hate speech issues. ${ }^{64}$

The 2008 report $^{65}$ contains a comprehensive chapter on hate speech, mentioning that besides anti-Roma manifestations, anti-Semitism is also prevalent, ${ }^{66}$ and includes a section on the increase in physical violence against Roma as well. As for physical attacks against Roma (or property owned by Roma), the report mentions ten cases (noting that the media reported on an even larger number of cases). ${ }^{67}$

In November 2008, the Parliamentary Commissioner considered an attack against a Roma family in Pécs as a crime with "significant impact on public concerns over safety", and expressed his worries because the police almost immediately dismissed the possibility of racist motivations. ${ }^{68}$ The Parliamentary Commissioner released a statement as well, concerning other attacks against Roma, following consultation with several Roma public figures, calling the authorities to pay special attention to exploring the possible bias motivation behind the crimes. ${ }^{69}$

The Parliamentary Commissioner's report on 2009 calls on ${ }^{70}$ authorities to collect individual data of the perpetrators and victims of hate crimes, as well to establish a monitoring system regarding racist attacks and incidents.

In a 2010 report on an investigation ${ }^{71}$ initiated ex officio by the Parliamentary Commissioner, ineffective police response is criticised concerning an incident, involving a rural Roma community, which took place in the context of local ethnic tensions.

${ }^{63}$ Hereinafter referred to as Jobbik.

${ }^{64}$ Parliamentary Commissioner for National and Ethnic Minority Rights of Hungary: Beszámoló a nemzeti és etnikai kisebbségi jogok országgyülési biztosának tevékenységéröl, 2007 (Report on the activity of the Parliamentary Commissioner for National and Ethnic Minority Rights in 2007). Budapest, 2008, 79, available at http://3ddigitalispublikacio.hu/media/ombudsman/beszamolo_2007.pdf

65 Parliamentary Commissioner for National and Ethnic Minority Rights of Hungary: Beszámoló a nemzeti és etnikai kisebbségi jogok országgyülési biztosának tevékenységéröl, 2008 (Report on the activity of the Parliamentary Commissioner for National and Ethnic Minority Rights in 2008). Budapest, 2009, available at http://www.kisebbsegiombudsman.hu/data/files/144644490.pdf

66 Ibid. 152.

67 Ibid. 166.

68 Parliamentary Commissioner for National and Ethnic Minority Rights of Hungary: Újabb romák elleni támadás (Another attack against Roma) (Press release, 19th of November, 2008), available at http://www.kisebbsegiombudsman.hu/hir-385-jabb-romak-elleni-tamadas.html

69 Parliamentary Commissioner for National and Ethnic Minority Rights of Hungary: Véletlen, sorozatos egybeesés vagy aggodalomra okot adó tendencia? (Accidental series of coincidencies or a worrisome tendency?) (Statement, 19th of November, 2008), available at: http://www. kisebbsegiombudsman.hu/hir-386-allasfoglalas-az-elmult-evben-tortent.html

70 Parliamentary Commissioner for National and Ethnic Minority Rights of Hungary: Beszámoló a nemzeti és etnikai kisebbségi jogok országgyülési biztosának tevékenységéről, 2009 (Report on the activities of the Parliamentary Commissioner for National and Ethnic Minority Rights in 2098). Budapest, 2010, 40, available at http://www.kisebbsegiombudsman.hu/data/files/185232828.pdf

${ }^{71}$ Parliamentary Commissioner for National and Ethnic Minority Rights of Hungary: A nemzeti és etnikai kisebbségi jogok országgyülési biztosának jelentése a 2009. november 15-16-i sajóbábonyi eseményekröl és az azzal összefüggö jogértelmezési problémáról (Report of the Parliamentary Commissioner for National and Ethnic Minority Rights on the incidents on 15-16 November 2009 in 
The last yearbook ${ }^{72}$ of the National Security Office, published in $2009,{ }^{73}$ contains a detailed chapter devoted to extremist groups, focusing on the sweep of the extreme-rightist, anti-Roma political forces, the phenomenon of the paramilitary organisation Hungarian Guard (and its activities, e.g. marches aimed at intimidating Roma communities). The report indicates an increase in attacks against LGBT people as well (referring to the violent incidents around the 2008 Gay Pride March in Budapest).

\section{Unofficial data and information on anti-Roma hate crimes}

The reports published by the European Comparative Minority Research Foundation are a rich source of information on Roma issues, including hate crimes. ${ }^{74}$ Mainstream media also reported on hate crimes against Roma, especially concerning a series of nine attacks ${ }^{75}$ committed in 2008 and 2009, allegedly by an organised group of criminals.

The media dealt first of all with the above-mentioned nine attacks, resulted in deaths, injuries and loss of the properties of Roma people. These crimes were apparently targeted against the homes of Roma people living in the outskirts of rural settlements (in neighbourhoods with a significant Roma population). The perpetrators used self-made firebombs ("Molotov cocktails"), to set the buildings on fire, and handguns for the fatal attacks.

Sajóbábony and the related problems regarding legal interpretation) (reg. no. 18/2010), available at http://www.kisebbsegiombudsman.hu/hir-550-jelentes-2009-november-15-16-i.html

72 NBH: A Nemzetbiztonsági Hivatal Évkönyve. 2008 (Yearbook of the National Security Office, 2008). Budapest, 2009, available at http://www.nbh.hu/oldpage/evk2008/001menu.htm.

73 The yearbook was last published in 2009. After the governmental changes in 2010, the National Security office was reorganised (and renamed to Constitution Protection Office).

74 Their latest report is EÖKK: Cigánynak lenni Magyarországon. Jelentés 2008 (To be a Roma in Hungary. Report 2008). Budapest, 2009.

75 The 1st attack in the series of nine took place in Galgagyörk, a village near Budapest, where shortly after midnight, 10-15 shots were fired at three houses owned by Roma. No one was injured. The 2nd attack was committed in Piricse, where Molotov cocktails were thrown at two houses owned by Roma people. A woman was shot on her leg when she stepped out of one of the houses. The 3rd attack was perpetrated in Nyíradony, where gunshots were targeted at a house inhabited by Roma. No one was injured. The 4th attack took place in Tarnabod, where Molotov cocktails were thrown and gunshots fired at three homes in a neighbourhood with a significant Roma population. No one was injured. On 3 November 2008, the 5th attack was committed in Nagycsécs, where a 43-year-old Roma man and a 40-year-old Roma woman were shot dead in their home in Nagycsécs. According to the official investigation, petrol bombs (Molotov cocktails) were thrown into the house before the perpetrators used firearms to kill the members of the family. On 15 December 2008, the 6th attack took place in Alsózsolca, where several shots were fired at a 19-year-old Roma man and his partner in front of their home in Alsózsolca. The young man suffered life-threatening injuries. On 23 February 2009, the 7th attack was committed in Tatárszentgyörgy: a 27-year-old Roma father and his 5-year-old son were shot dead as they ran out of their burning home in Tatárszentgyörgy. The man's wife and the couple's two other children were also seriously injured in the attack and had to be treated for severe burns. On 22 April 2009, the 8th attack was committed in Tiszalök when an 54-year-old Roma man was shot in the chest outside his home. On 3 August 2009, the 9th-last-crime took place in Kisléta, where a 45-year-old Roma woman was shot dead, and her 13-year-old daughter seriously injured in an attack against their home in Kisléta. The girl, suffering life-threatening injuries, remained in hospital for several weeks. 
Besides these crimes, "sporadic" incidents, with alleged/possible anti-Roma motivation in the background, were reported by the media in numerous cases, especially in 2008 and 2009 .

\section{Unofficial data and information on anti-Semitic hate crimes}

The Hungarian mainstream media provides with information on anti-Semitic incidents: violence against persons ${ }^{76}$ and property. ${ }^{77}$ The Alliance of the Jewish Religious Communities of Hungary collects information on anti-Semitic attacks and abuses.

\section{Unofficial data and information on other racist or other religiously motivated hate crimes}

There is no information about systematic collection of unofficial data regarding on other racist (e.g. against people of colour) or other religiously motivated (e.g. Islamophobic) hate crimes in Hungary.

According to the available sources, no violent incidents against foreigners were reported during the last two years by migrants or refugees. However, according to 2009 research report on migrants living in Hungary, the interviewed third country nationals "preferred not to talk about any racist incidents experienced by them, however, during the conversations, some of them mentioned that radicalisation-in connection with recent the political tendencies-and the sweep of the right-wing is perceivable". ${ }^{78}$

\section{Unofficial data and information on homophobic hate crimes}

The sources of unofficial data and information on homophobic hate crimes provided in Hungarian context are: personal accounts of members of LGBT organisations; websites of LGBT organisations and human rights and NGOs providing legal support for victims $;{ }^{79}$ the "Háttér Archives" (maintained by Háttér Society) $;{ }^{80}$ which is a rich source of media reports, press releases, legal and other documents; press releases, complaints and cases published by

76 The mainstream media dealt with two cases: in July 2009, three men abused a 27 -year-old Jewish man in a neighbourhood of Budapest where a significant Jewish population lives $\left(7^{\text {th }}\right.$ district, Dohány street), because he admitted his Jewish origin; in March 2010, the police warning came after a rabbi's home was attacked by anti-Semitic vandals who smashed the windows with stones during a seder holiday meal.

77 The mainstream media reported the following cases: in December 2009, the day after a conference held in the Parliament, where Elie Wiesel, Nobel Prize winner novelist was present as a keynote speaker, unknown perpetrators vandalised 12 gravestones and a statue in the Jewish cemetery of Székesfehérvár, and painted on the wall of the Memorial Hall the words "We don't need a Jewish Casino"; in July 2010 altogether 13 (150-200 years old) gravestones were vandalised by unknown perpetrators in the Jewish cemetery of Tolna.

78 Within the framework of a comprehensive research on migrants (third country nationals), 70 interviews were proceeded with migrants and experts (among the latter group there were migrants as well). The interviewees came altogether from 23 foreign countries (Vietnam, China, Turkey, Nigeria, Senegal, Gambia, Ghana, Iran, Libya, Russian Federation, Syria, Ukraine, Afghanistan, Benin, Egypt, The Emirates, Ethiopia, Iraq, Kenya, Mongolia, Peru, Romania, and Tibet). See Bognár: op. cit. 147.

${ }^{79}$ Labrisz Lesbian Association, Háttér Society for LGBT People, Szimpozion Association: http://www.szimpozion, PATENT Human Rights Association, Amnesty International Hungary, Hungarian Civil Liberties Union.

${ }^{80}$ Háttér Archívum, http://www.hatter.hu/hatter-archivum 
the above mentioned organisations; the mainstream media; ${ }^{81}$ the community media (LGBT news sites, Facebook and other community sites where LGBT and other human rights organisations are present); and blogs. Extremist websites in Hungary also regularly report homophobic hate crimes considered as "success stories' and 'acts of justice". ${ }^{82}$

\section{Information on anti-Roma hate crime from foreign sources and international organizations}

The European Commission against Racism and Intolerance (ECRI), the Council of Europe's independent human rights monitoring body published its latest Report on Hungary ${ }^{83}$ in February, 2009, where it "urges the Hungarian authorities to intensify their efforts to ensure a more vigorous implementation of criminal law provisions relating to the fight against racism" ${ }^{84}$ and "reiterates its recommendation that further human and financial resources be allocated to measures aimed at ensuring that the investigation and prosecution of racist crimes are carried out in a thorough and systematic fashion". ${ }^{85}$

According to the 2010 report of the Minority Rights Group ${ }^{86}$ "Jobbik blames Jews and Roma for the social and economic problems facing Hungary post-transition and postEU accession" and "It has also coined the term 'Gypsy crime' to denote certain types of crimes supposedly committed exclusively by Roma".

The U.S. Bureau of Democracy, Human Rights, and $\mathrm{Labor}^{87}$ provides with an assessment regarding the legal framework of hate crimes and hate speech, and of the implementation of the law as well: "Courts have failed to convict persons of inciting hatred when no physical assault followed. Under the civil code, a person specifically targeted by hate speech may file a civil suit, but, as long as the speech remains abstract and does not

${ }^{81}$ For example. the following cases were reported by mainstream media. In May, 2009, at the Heroes'Square in Budapest, a group of skinhead-looking people (one of them wearing the hat of the Hungarian Guard) verbally insulted the participants of a film-shooting, preparing a video spot announcing the forthcoming Gay Pride, and spat at one of the participants, a young, foreigner woman. In 2009 (5 September), 41 extremists were arrested in relation to violent activities during the Gay Pride. Prosecution was started against 27 of them. Near the venue of the afterparty of the Pride extremists were gathering, and launching verbal attacks, and threw stones at one police car patrolling around the venue. Two men leaving the after-party on bicycles were attacked by extremists, the victims suffered serious injuries. After the Gay Pride March in 2009 (5 September), one woman wearing the organisers' T-shirt was attacked on the street by two or three men on her way home.

82 About a week after the Gay Pride, in July 2010, a group of extremists announced on their website, using hate speech, that they "desecrated" the gravestone of Károly Kertbeny. (Károly Kertbeny was a 19th century Hungarian writer who invented the words "homosexuality" and "heterosexuality". A gravestone was erected for him in 2002 by the LGBT community, and it is visited every year by participants of the LGBT Festival.) The extremists covered the memorial with a black sack and attached a quote from the Bible saying that men having sexual relations with men have to die.

83 ECRI: Report on Hungary, fourth monitoring cycle (adopted on 20 June 2008, published on 24 February 2009), available at http://www.coe.int/t/dghl/monitoring/ecri/country-by-country/ hungary/HUN-CbC-IV-2009-003-ENG.pdf

84 Ibid. Para. 25.

85 Ibid. Para. 26.

${ }^{86}$ MRG International: State of the World's Minorities and Indigenous Peoples 2010. Events of 2009. London, 2010, 161, available at: www.minorityrights.org/download.php?id=840

87 U.S. Bureau of Democracy, Human Rights, and Labor: 2009 Human Rights Report: Hungary. 2010, available at http://www.state.gov/g/drl/rls/hrrpt/2009/eur/136035.htm 
mention any specific individual, there is no legal recourse". The series of physical attacks against Roma (between June 2008 and 3 August 2009) are also reported, and the criticism raised among anti-racist activists by the shortcomings of the investigation, and that the police ordered an internal disciplinary proceeding to examine the alleged mistakes, and these resulted in sanctions against two police officers. The report mentions that after the arrest of four suspects on 21 August 2009, "No additional attacks of this nature occurred". The report provides with details regarding notable racist manifestations in the public life. ${ }^{88}$

The Amnesty International 2010 report $^{89}$ states that violent attacks against Roma continued in $2009,{ }^{90}$ presents details on three murder cases, and mentiones that: "In September, about 400 Romani women initiated legal proceedings against Oszkár Molnár, a Member of Parliament of the opposition FIDESZ party and Mayor of Edeleny, over his alleged defamatory remarks on Romani women". ${ }^{91}$

The Freedom House reports" "increasing violence against Roma led to four deaths in 2009, and rising insecurity forced Romany men to patrol their own neighbourhoods", and mentions that "four men were arrested in August 2009 in connection with the murders".

88 Ibid. [30 January 2009] "Albert Pásztor, the head of the Miskolc police headquarters, stated in a press conference, 'Hungarians appear to rob banks or gas stations, but all the other robberies are committed by Gypsies' [...] and that 'cute Gypsy children often become rude and cruel perpetrators'. Upon the instruction of the minister of justice and law enforcement, the HNP [Hungarian National Police] initiated an inquiry into the incident, and Pásztor was suspended from his position. However, two days later the investigation concluded that Pásztor did not break any law, and the HNP terminated his suspension; the decision to reinstate Pásztor was approved by the minister of justice and law enforcement."; [2 April 2009] "Parliamentary Commissioner for Civil Rights Szabó stated in an interview that 'Gypsy crime' existed and defined it as a type of crime performed to earn a living. [...] $\mathrm{He}$ also presented himself as the parliamentary commissioner of the 'majority' rather than the parliamentary commissioner for the rights of national and ethnic minorities. Although he withdrew his statement the next day following strong criticism by human rights groups, Szabó's professional acceptance greatly weakened following this incident."; [3 September 2009] "Oszkár Molnár, the mayor of Edeleny and a FIDESZ parliamentarian, stated during a press conference that pregnant Romani women hit their bellies with rubber hammers and took harmful medicines to increase the chance their child would be born with disabilities in order to receive increased state financial aid. Responding to the statement, FIDESZ party leaders initially labelled it as a 'local issue'. However, in December the center-right FIDESZ party dropped Molnár from its slate for the April 2010 parliamentary elections."

89 Amnesty International: Amnesty International Report 2010. The State of The World's Human Rights, 2010, 166, available at http:/thereport.amnesty.org/sites/default/files/AIR2010_EN. pdf, "Robert Csorba and his son, aged five, were killed in Tatárszentgyörgy in February. After an initial examination, the local police announced that they had been found dead after a fire caused by an electrical fault in their house. Later that same day, however, the police acknowledged that evidence of gunshot wounds had been found on the bodies, but only opened a murder investigation 10 hours later." "Jenő Koka, a 54-year-old Romani man, was killed in Tiszalöks Roma neighbourhood in April. He was reportedly shot dead as he left his home to start the night shift in the local chemical factory where he worked." "Maria Balogh, a 45-year-old Romani woman, was shot dead and her 13-year-old daughter seriously injured in the village of Kisléta in August".

90 Ibid. 165-166.

91 Ibid.

92 Freedom House: Country Report, Hungary. 2010, available at http://www.freedomhouse.org/ template.cfm?page $=22$ \&year $=2010$ \& country $=7838$ 


\section{Information on anti-Semitic hate crime from foreign sources and international organizations}

The European Commission against Racism and Intolerance stated in its report, concerning the situation before June 2008, ${ }^{93}$ that "antisemitic attacks against persons appear to be rare, incidents of vandalism against synagogues and Jewish cemeteries are not uncommon", 94 and reports that for "Antisemitism has also been openly espoused by certain political parties, NGOs report that even some mainstream parties do little to distance themselves from such opinions. Overall, the sense is that the expression of antisemitic views is currently on the rise in Hungary". ${ }^{95}$

The latest report of the U.S. Bureau of Democracy report on human rights ${ }^{96}$ states that $^{-1}$ during 2009 anti-Semitic incidents, including vandalism, continued, but the Federation of Jewish Communities in Hungary reported that anti-Semitism did not increase in the year compared with 2008: "According to police there were 124 reports of vandalism or destruction of Jewish and Christian properties (nine in houses of worship and 115 in cemeteries) during the first ten months of the year compared with 365 cases reported in 2008". Besides mentioning that anti-Semitism is present in the media, anti-Semitic incidents ${ }^{97}$ were also reported by the U.S. Bureau of Democracy.

${ }_{93}$ ECRI: Report on Hungary (fourth monitoring cycle). Adopted on 20 June 2008, published on 24 February 2009, available at http://www.coe.int/t/dghl/monitoring/ecri/country-by-country/hungary/ HUN-CbC-IV-2009-003-ENG.pdf

94 Ibid. Article 72.

95 Ibid. Article 73.

96 U.S. Bureau of Democracy, Human Rights, and Labor: 2009 Human Rights Report: Hungary. 2010, available at: http://www.state.gov/g/drl/rls/hrrpt/2009/eur/136035.htm

97 [24 February 2009] "The World Jewish Congress joined MAZSIHISZ in criticising antiSemitic comments made by a local government official, Attila Kiss from Rajka. Kiss called on other officials to take up 'sickles and swords' and 'exorcise' the local synagogue. MAZSIHISZ lodged an official complaint against Kiss, which the Prosecutor's Office subsequently rejected.”; [4 April 2009] "Jobbik, Magyar Garda, and the Hungarian National Front co-organised an event commemorating the 1882 'blood libel' trial in which residents of Tiszaeszlar accused the local Jewish community of killing a 14-year-old Christian peasant girl in order to use her blood for a religious ceremony. The police ordered an investigation into the event after the media reported that the approximately 80 participants made anti-Semitic comments. On December 3, the police concluded the investigation due to the lack of evidence of the crime of 'incitement against a community'."; [18 April 2009] "A day before the March of the Living procession organised by the Jewish communities, far-right demonstrators marched to the German embassy in Budapest to deny the Holocaust and to raise their voices against 'Zionist world-rule'. An estimated 250 persons, including 60 wearing Magyar Garda uniforms, held posters reading, 'Down with the Holocaust doctrine' and 'the Third Reich strikes back'. Others wore shirts that said 'Dare to be white'. MGA [Magyar Gárda-Hungarian Guard] Captain Istvan Dosa said in a speech that "nothing from the Holocaust is true", and then he read a petition addressed to the German embassy. The Budapest police initiated legal procedures against Dosa and another speaker for "incitement against a community". However, the participants also made an official complaint concerning police actions in connection with the march, which the prosecutor's office supported. Consequently, the police dropped their investigation of the march."; [30 June 2009] "Three men beat a 27-year-old Jewish man after asking if he was a Jew. The victim suffered minor injuries. The prime minister asked the minister of justice and law enforcement to supervise and accelerate the investigation and to present proposals on how to avoid similar incidents. On December 23 the police arrested two persons, one 16 years old and the other 18 years old, in connection with the attack and initiated an 
The Office for Democratic Institutions and Human Rights of the Organisation for Security and Co-operation in Europe launched a report in June $2010^{98}$ about the outcomes of a field assessment visit in Jun-July 2009, aimed at exploring the context of the violent attacks against Roma in Hungary in 2008-2009. According to the report: "Convictions on charges of inciting hatred against a community are rare, as the relevant practice of the Constitutional Court requires the prosecution to show a direct causal connection between hate speech and an incident of violence. The delegation heard concerns that current hatespeech laws provide 'unlimited' free speech, leaving broad opportunities for the dissemination of racist propaganda". The report mentions that there are apparently "no specific instructions or guidelines on the investigation of hate motivation or its consideration as an aggravating circumstance in crimes." The report contains detailed recommendations ${ }^{99}$ to the relevant Hungarian authorities, with regard to combating racist hate crimes and preventing further incidents. In Appendix, ${ }^{100}$ a comprehensive list is presented of 45 incidents with an alleged racist motivation, involving Roma victims (22 cases from 2008, 23 cases from 2009). As for 2010, the report states "in the first quarter of this year, two new attacks against Roma were reported by civil society". ${ }^{01}$

\section{Information on other racist hate crime from foreign sources and international organizations}

The only information on "other" racist hate crime is reported by U.S. Bureau of Democracy: "Five Roma were charged with a racist assault after allegedly beating an ethnic Hungarian on September 23. The four men and a woman were placed in pre-trial detention. According to a police spokesman, this was the country's first racist incident in which the victim was not a member of a minority". ${ }^{102}$

investigation of violence against a member of a community"; [5 September 2009] "During a pride parade, approximately 20 demonstrators whom police had pushed out of Városház Square began shouting 'nasty Jews' in the direction of Budapest's largest synagogue. The demonstrators threw an empty beer bottle at the synagogue and tore down a hanging banner advertising the Jewish Summer Festival. They set the banner, along with a temporary reed fence near the synagogue, on fire. Police quickly extinguished the fire. They opened an investigation into the incident"; [26 October 2009] "A 22-year-old man smashed a memorial plaque dedicated to Armin Kecskeméti, chief rabbi of Mako for more than 40 years, who died in a concentration camp in 1944. The perpetrator also wrote 'what six million?' and "lying swine" on the wall. Two days later the police captured a suspect and initiated proceedings against him on vandalism charges."

98 OSCE-ODIHR: Addressing Violence, Promoting Integration. Field Assessment of Violent Incidents against Roma in Hungary: Key Developments, Findings and Recommendations. June-July 2009. Warsaw, 15 June 2010, available at http://www.osce.org/documents/odihr/2010/06/44569 en.pdf

99 Ibid. Chapter 7, "Recommendations".

100 Ibid. Appendix 1, "Incidents and Violence against Roma in Hungary in 2008-2009".

101 Ibid. 4.

102 U.S. Bureau of Democracy, Human Rights, and Labor: 2009 Human Rights Report: Hungary. 2010, available at http://www.state.gov/g/drl/rls/hrrpt/2009/eur/136035.htm 
Information on homophobic hate crime from foreign sources and international organizations

The latest Amnesty International report ${ }^{103}$ mentions that the 2009 LGBT Pride March in Budapest on 5 September 2009 was protected adequately by the police with and no incidents reported during the march, however "a young woman was allegedly attacked by two or three anti-gay protesters after the march; she suffered injuries on her head and arms".

The 2010 report of the U.S. Bureau of Democracy report on human rights ${ }^{104}$ states that "extremist groups continued to subject gay men and lesbians to physical abuse and attacks", and reports the same attack (attack against a young woman), noting that after the Hungarian Civil Liberties Union complained to the national police chief that the reason for the assault was related to the woman's membership in a societal group, police changed the legal grounds of the investigation to "violence against a member of a community".

The 2009 report of the Danish Institute for Human Rights on Hungary ${ }^{105}$ concludes that hate speech is only "covered by the law when it amounts to incitement to hatred against a community". The report indicates that "No good practices have been identified in Hungary" 106 in the field of combating homophobia and discrimination on the grounds of sexual orientation and gender identity.

As for the Hungarian legislation regarding homophobic hate crimes, the ILGA Europe's ${ }^{107}$ Country Index ${ }^{108}$ emphasizes that the relevant criminal law does not refer explicitly to homophobia as a bias motive.

\section{Positive initiatives aimed at preventing and hate crimes}

The regulation of operations, ethics, and procedures with respect to content providing (Code of Content Providing), ${ }^{109}$ issued by the Hungarian Association of Content Providers (last supervised in 2009) takes stance against hate speech, and provides editors with guidance regarding extremist manifestations and insulting expressions: "The Content Provider should strictly avoid expressions that are insulting to particular persons or groups of persons, as well as extremist manifestations of other kinds. Where it is appropriate, it may, however, give space to such views expressed by public persons: in such cases, it should be made

103 AI: Amnesty International Report 2010. The State of The World's Human Rights, 2010, 166, available at http://thereport.amnesty.org/sites/default/files/AIR2010_EN.pdf

104 U.S. Bureau of Democracy, Human Rights, and Labor: 2009 Human Rights Report: Hungary. 2010, available at http://www.state.gov/g/drl/rls/hrrpt/2009/eur/136035.htm

105 Danish Institute for Human Rights, COWI: The social situation concerning homophobia and discrimination on grounds of sexual orientation in Hungary. March 2009, available at http://fra. europa.eu/fraWebsite/attachments/FRA-hdgso-part2-NR_HU.pdf

106 Ibid. Art. 43.

107 International Lesbian, Gay, Bisexual, Trans and Intersex Association, Europe, http://www. ilga-europe.org/

108 ILGA (2010) Rainbow Europe Map and Country Index (May 2010), available at: http://www. ilga-europe.org/home/publications/reports_and_other_materials/rainbow_europe_map_and_country_ index_may_2010.

109 MTE: A Magyarországi Tartalomszolgáltatók Egyesületének a Tartalomszolgáltatásra Vonatkozó Működési, Etikai és Eljárási Szabályzata (Code of Conduct, Ethics and Procedures of Content Providing, issued by the Hungarian Association of Content Providers). 2009, (last supervised: 21 October 2009): http://www.mte.hu/etikaikodex.html 
clear that the Content Provider does not agree with this view, considering it incompatible with its own basic principles. It is the duty of the editors to determine the most appropriate way of noting this in every case". ${ }^{110}$

As (racist or anti-Semitic) extremism among football fans is a prevalent phenomenon in Hungary, the Hungarian Football Federation implemented regulations, to prevent/ eliminate hate speech and racist incidents before/during/after matches. The contents of these documents are in accordance with the recommendations of the international football organisations (UEFA-Union of European Football Associations, FIFA Fédération Internationale de Football Association), with a detailed regulation on the responsibility of sport organisations, on the tolerable behaviour of spectators, and on the applicable sanctions (including fines). According to the Security Regulations which regulated the rules and conditions of the participation at matches, it should be printed on the tickets that racist or ant-Semitic expressions are forbidden, ${ }^{111}$ and, in cases of racist or scandalous manifestations, the match might be interrupted or even closed. ${ }^{112}$ The Code of Discipline contains regulations on the "banner permission" (only those banners might be brought into the grandstands that are checked by a special commission-e.g. racist/anti-Semitic slogans are forbidden ${ }^{113}$ Racist/intolerant behaviour or expressions (and defamation as well) are considered as misdemeanours to be sanctioned. ${ }^{114}$ The Disciplinary Committee of the Federation regularly fines sport organisations those fans violate of the regulations. ${ }^{115}$

There are NGOs providing legal counselling and assistance to victims of hate crimes: e.g. the Hungarian Civil Liberties Union ${ }^{116}$ and the Háttér Society for LGBT People ${ }^{117}$ (the latter focuses on victims of homophobic attacks.

The Háttér Society for LGBT People launched a project within the framework of the EU PROGRESS Programme ${ }^{118}$ aimed at providing police officers with trainings regarding homophobic hate crimes. The project, started in May 2009, contains a module which

110 Ibid. Sec. V: "Separation of the public and private spheres", Art. 1 "Protection of personality rights".

111 Magyar Labdarúgó Szövetség Biztonsági Szabályzata (Security regulations of the Hungarian Football Federation) (adapted on 16 April 2009) http://www.mlsz.hu/anyagok/szabalyzat/2009-2010/ Biztonsagi_Szabalyzat.pdf, Appendix 8, Article 4.4.

112 Ibid. Appendix 8, Art. 5.

113 Magyar Labdarúgó Szövetség Fegyelmi Szabályzata (Code of Discipline of the Hungarian Football Federation) (came into force on 1 July 2009, last modified: 25 June 2010) http://www.mlsz. hu/anyagok/szabalyzat/2009-2010/Fegyelmi_Szabalyzat, Appendix 9.

${ }_{114}$ Ibid. Disciplinary Sanctions, Sec. III, Art. 10. The Code sets the maximum limits of fines. In cases of such misdemeanours, players should be excluded at least 5 matches from participation, members of the audience might be banned from the stadium for 2 years. Clubs might be fined and/or ordered to organise closed-door matches because of the misdemeanour of their fans; or might be sanctioned with championship score reduction, or even with re-classification to a lower league.

115 In 2010, the media reported several disciplinary decisions against football clubs because of anti-Semitic/racist hate speech on the grandstands, involving fines of 100-400,000 HUF (approx. 400-1,600 EUR).

$116 \mathrm{http}: / /$ tasz.hu/jogsegely

$117 \mathrm{http}: / /$ www.hatter.hu/jog

118 The project is implemented within the framework of Hungarian programme "Együtt az egyenlöségért 2009-2010" (Together for Equality 2009-2010), co-funded by the EU PROGRESS Programme. The call for proposals was launched by the Hungarian Ministry of Social Affairs and Labour (applications were selected by public procurement procedure). 
addresses police officers, and focuses on combating homophobic hate crimes and awarenessraising on LMBT issues. The training materials are prepared by expert groups, with the participation of researchers (Open Society Institute, Central European University, Max Planck Institute) and NGO activist (Háttér Society Legal Defence Bureau for National and Ethnic Minorities), and a member of the Advisory Committee of the Hungarian Equal Treatment Authority.

\section{Conclusions}

In the Hungarian context, it is almost impossible to draw valid conclusions regarding the extent, trends and forms of racist violence and other forms of hate crimes on the basis of official criminal justice data and information. Very few reports are filed on criminal offences that contain a racial or other bias motivation element, and even fewer lead to indictment. Similarly, due to the small number of cases that are actually recorded as criminal offences by the prosecution no valid conclusions could be drawn with regard to the specific characteristics of offenders. Data on the demographic features of victims are not collected by the Hungarian authorities.

Given the lack of a specified monitoring mechanism on hate crimes, and appropriate official information, other sources like reports of NGOs and international organizations have to be considered as well. Regarding homophobic hate crimes, LMBT organizations report a decrease of the number of extremist homophobic offenders at the Pride March 2009 and 2010, compared to 2008, due to the police strategy (isolating the route of the March) and to a change in legislation. As for anti-Roma hate crimes, unofficial sources (first of all, the media and NGOs) agree on the perception of unprecedented sweep of violence against the Roma community in Hungary in 2008-2009. This tendency ended, apparently in August 2009, with the arrest of four suspects of a series of nine attacks against Roma.

However, by the time of closing the manuscript of the present article, new forms of hate motivated hate crimes are emerging in Hungary, targeting especially certain Roma communities in rural areas. These worrisome tendencies are being followed by legislative changes and initiatives, however, there are still apparent shortcomings with implementation of the current laws to combat hate crimes. 